Original Research Paper

\title{
An Empirical Analysis of Supply Response of Rubber in Malaysia
}

\author{
Ghulam Mustafa, Ismail Abd Latif and Henry Egwuma \\ Department of Agribusiness and Bioresource Economics, \\ Faculty of Agriculture, Universiti Putra Malaysia, 43400 UPM Serdang, Selangor, Malaysia
}

\author{
Article history \\ Received: 11-10-2016 \\ Revised: 16-11-2016 \\ Accepted: 24-11-2016 \\ Corresponding Author: \\ Ismail Abd Latif \\ Department of Agribusiness \\ and Bioresource Economics, \\ Faculty of Agriculture, \\ Universiti Putra Malaysia, \\ 43400 UPM Serdang, Selangor, \\ Malaysia \\ Email: ial@upm.edu.my
}

\begin{abstract}
Supply response of rubber to changes in economic incentives is analysed using co-integration approach. Time series data is taken for the period 1990 to 2014 and the vector error correction model framework has been applied. The empirical results confirmed the existence of a unique long-run equilibrium relationship among planted acreage, the relative price of rubber and price of fertilizer. Further, the estimates suggested that rubber supply is significantly influenced by the relative price of rubber and the price of fertilizer. The estimated short- and long-run elasticities of acreage with respect to relative price are respectively 0.04 and 0.77 , while the short- and long-run elasticities of acreage with respect to fertilizer price are -0.20 and -0.28 respectively. The study recommends the design of an appropriate economic incentive structure to stimulate output and hence the income of farmers.
\end{abstract}

Keywords: Malaysia, Supply Response, Rubber, Vector Error Correction Model

\section{Introduction}

Rubber (Hevea brasiliensis) is an important perennial crop for the Malaysian economy and in 2015 the rubber industry contributed about $4.27 \%$ of national exports (Department of Statistics, 2016). The rubber product industry played a crucial role in the early postindependence economic development of the country and currently Malaysia is the third largest producer of Natural Rubber (NR) in the world with an output of 722,122 tonnes out of world production of 12.3 million tonnes and the fifth largest consumer of NR, with total consumption of 474,773 tonnes out of world consumption of 12.2 million tonnes. Malaysia is also among the major exporters of NR with 1.1 million tonnes while import is 957,300 tonnes. Malaysian's major exporting partners are China $(67.8 \%)$, Germany (8.1\%), Iran (3.6\%) and USA (3.2\%) (MRB, 2015).

As the Malaysian economic focus shifted from primary industries towards manufacturing sector, the rubber industry also underwent major fundamental changes. Malaysia was once the world's largest producer of NR but started to lose its position in the 1990s as a result of reallocation of resources to the other agricultural sectors. However, the decline in Malaysian production of NR over the last decade showed some reversal in trend, beginning from 2002 with output rising from 889,832 tonnes to 1.2 million tonnes in 2007 which again started declining up to 668,613 tonnes in 2014 . Nevertheless, Malaysia still maintains its position as the third largest NR producer in the world.

The rubber planted area is 1.06 million hectares while the harvested area is 734 thousand hectares. The average yield level of Malaysian natural rubber is 1,420 kilograms of Dry Rubber Contents (DRC) per hectare. This is quite low compared to that of countries such as Thailand which has emerged as number one as far as natural rubber productivity is concerned with a yield of $1,750 \mathrm{~kg}$ per hectare, India is second with a yield of $1,726 \mathrm{~kg}$ per hectare and Vietnam is third with a per hectare yield of $1,480 \mathrm{~kg}$. In terms of productivity, old rubber trees and new intensive clonal rubber trees exhibit marked differences. While the yield of old trees is on average about $540 \mathrm{~kg}$ of DRC per hectare (equivalent to 1.2 ton of slabs), the clonal rubber trees could yield about 1.35 ton of DRC per hectare or 3 ton of slabs (Arifin, 2005).

Given the above scenario, the government is currently revamping of the rubber industry. Accordingly, the government in line with vision 2020 and its 10th Malaysian Plan (MP) has set out new goals to enhance productivity and competitiveness and to modernize the predominant smallholders sector in order to maximize the industry's contribution to the national economy. In 
keeping with increased competitiveness and consumer demand, the Malaysian rubber industry will be additionally strengthened and broadened to incorporate a spectrum of activities with forward and backward linkages in both the upstream and downstream subsectors (10th Malaysian Plan, 2011; NKEA, 2011).

Furthermore, four Entry Point Projects (EPPs) have been implemented in the rubber industry with the aim of building the capacity of the industry to allow it to capture a bigger share of the global market. A major goal of the EPPs is to enhance rubber yield in Malaysia by ensuring that the planting materials supplied to smallholders are high-yielding and of the best quality. Consequently, the rubber National Key Economic Areas (NKEA) implementing agencies have been empowered to provide support and facilitate plans under the EPP. These agencies include the Rubber Industry Smallholders Development Authority (RISDA), Sabah Rubber Board (LIGS) and Malaysian Department of Irrigation and Drainage (JPS). A number of schemes have been undertaken through the EPP among which are the verification of clones at source bush nurseries, the establishment of Malaysian Rubber Budwood Centres (MRBC) and the adoption Good Agricultural Practices (GAP).

The rubber industry has changed the Malaysian economy into a profitable realm in tropical rubber business. According to the Malaysian Rubber Board, the Malaysia rubber industry has made outstanding progress in the area of environmental management in the last two decades through the execution and implementation of laws and strategies that border on sustainable development, thus making the rubber sector a multibillion industry. Despite all the efforts and the impressive performance of the industry, previous studies have identified key challenges that continue to plague the Malaysian rubber industry, notably including declining overall yields and output of rubber and saw logs due to a reduction in rubber hectarage, the rising cost of production, decline in controlled logging for sustainable forest management, diseases and pests, constraint in human resource and managing socioenvironmental issues. On other hand natural rubber also pollute to environment through it's by products (Tekasakul and Tekasakul, 2006) which require raising per capita income in ASEAN countries especially Malaysia, Indonesia and Thailand (Mustafa et al., 2016). These countries are also big producers of rubber in the world. This dynamic nature of rubber production calls for to revisit the supply response analysis of rubber production. The proposed study is designated to see the supply response of rubber production of Malaysia.

Two approaches can be identified on supply response analysis. First, at product level where the focus is on the change in the planted acreage or the product's composition in some cases with respect to the change in the price of commodity. Second, at aggregate level that incorporates change in total agricultural output with respect to the change in price, agricultural prices as well as industrial prices. In addition, previous studies on agricultural supply response have distinguished between the supply response of annual crops relative to perennial crops. Broadly, the supply response of perennial crop is quite different compared to annual crop. The supply of perennial crops has four distinctive characteristics. First, current year production not only depends on input usages but also previous year's output level. Second, perennial crops have a biologically-determined gestation period between planting and harvesting. Third, removal and replanting decisions are restricted by past decisions, technical condition of production, credit market situation and the availability of suitable land and labour. Fourth, there are significant costs of adjustment which restrict the planting and removal of trees. The first two characteristics indicate that the supply theory for perennial crops is dynamic. However, separately and collectively, all these characteristics imply that producers must have foresight or long-term planning with reference to investment. In particular, the productivity of such yield-bearing perennials as trees for any given level of inputs generally depends on a biologically-determined life-cycle (Akiyama and Trivedi, 1987). The theory and empirical methods of analysing the supply response of perennials is therefore different from methods employed to analyse annual crops.

In order to increase farm production and income, market-oriented agricultural pricing policy has been a crucial tool. The effects of such policies could best be examined by analyzing and quantifying output response to price changes (Nerlove and Bachman, 1960; Mohammad et al., 2007; Mushtaq and Dawson, 2002). Therefore, supply response analysis is a tool used to evaluate the success and effectiveness of pricing policies regarding allocation of farm resources and provides inputs for formulating economic policy in agricultural production. Hence, our main objective is to determine the supply response of rubber crop to economic incentives by estimating a vector error correction model to uncover the short-run and long-run relationship between key variables.

Based on above discussion the proposed study will contribute in the literature by following ways. First, empirical point of view, this study deeply looked into the factor affecting the production of rubber so that farmers' competitiveness and hence their earnings can be increased. This is also the main agenda of Malaysian government in 2020 plan to push the farmers out of the middle income trap. Second, most of previous research regarding supply response can be found on annual crops however, research is under process regarding perennial crops. Due to dynamic nature of perennial crop-rubber- a separate study require to see the distinguish function of 
supply response. This study designated to fill this gap. Third, there has been a transfer of resources such as land and other inputs from the rubber industry to the oil palm sector so that is why, as can be seen in methodology part, we took relative price of rubber to palm oil. This is the classic additional variable that has not covered yet in context of rubber. Hence, this study filled this gap by incorporating relative price of rubber to palm oil. Fourth, methodological point of view, we used the Augmented Dicky-Fuller (ADF) and Phillips-Perron (PP) unit root test to identify the order of each time series. Due to the distinct nature of rubber where farmers current production decision is dependent on past years' outputs so we applied the Ljung_Box Q-statistic to test for autocorrelation of error term while the Schwarz Information Criterion (SIC) is used to determine the optimal system lag order. Further, we used JohansenJulius cointegration method to examine the supply response function of rubber which is considered better than Engle-Granger method on which most of the previous studies are based.

The structure of the rest of the paper is as follows: The second section highlights the theoretical and empirical literature of supply response of both annual and perennial crops. The empirical approach adopted is given in the third section while the fourth section presents and discusses the results. The paper is concluded in the fifth section.

\section{Literature Review}

In recent decades the literature on the supply response of agricultural commodities has occupied a central position in agricultural economics. In addition to providing useful insights into the effect of government policies on the supply responsiveness of farmers, the analysis of supply helps to ascertain the profitability of agricultural production (Devadoss and Luckstead, 2010). A review of the literature shows that several studies have been conducted on the supply response of both annual and perennial crops (Alston et al., 1980; Bateman, 1965; Behrman, 1968; Elias and Okorie, 2014; French and Matthews, 1971; Gunawardana et al., 1995; Huq et al., 2013; Huq and Arshad, 2010; Kumar and Sharma, 2006; Mesike et al., 2010; Mushtaq and Dawson, 2002; Ozkan et al., 2011; Shahbaz et al., 2013; Talib, 1988; Tripathi and Prasad, 2009).

For example, Bateman (1965) modelled the Ghanaian cocoa industry based on the Nerlove-type adaptive price expectation framework and found that cocoa planting decision is significantly influenced by own-price and competitive coffee price. On his own part Behrman (1968) applied the Nerlovian partial adjustment approach to examine the production of cocoa in some major producing countries. By developing a model with desired area planted as a function of the producer's price expectations for both cocoa and the competing crop, coffee. Behrman obtained estimates of the coefficients of the variables in the equations for eight major cocoa producing countries. French and Matthews (1971) attempted the estimation of supply response for asparagus by developing a model consisting of equations for plantings, removals and yield and output variations. Their study set out a theoretical framework that has continued to be applied, with modifications, to the analysis of supply response of perennial crops.

Econometric approach to the analysis of supply response of agricultural commodities can be divided into three categories; direct estimation of the supply function, two-stage approach or indirect approach and the cointegration approach. Due to its importance and advantages over other methods, this study employs the cointegration approach. The recent works in the field of agricultural economics mostly focussed on cointegration and hence, error correction studies of time series data. Using cointegration and vector error correction approach, Mesike et al. (2010) analysed the supply response of rubber farmers to changes in prices and other factors in Nigeria for the period from 1970 to 2008. They found the estimated own-price elasticity of rubber supply to be 0.037 in the short-run and 0.204 in the longrun which is quite low. Similarly, the supply response of potato in Bangladesh was analysed by Huq and Arshad (2010) using vector error correction approach based on data covering 1982 to 2006 . They found the short-run and long-run price elasticities to be 0.45 and 0.62 respectively, confirming the effectiveness of price policies in achieving the desired production level for potato in Bangladesh. Similarly, Rahji et al. (2008) found that time trend has significant effect on yield, area and output of rice based on the estimation of a Nerlovian adjustment model for Nigerian rice using annual data from 1967 to 2004 . They also found both the short-run and long-run price elasticities to be inelastic.

Pipitkul (2004) estimated the supply response of rubber in Thailand using simultaneous equation approach with time series data from 1975-2002. He estimated supply equation as actual production in a given time period as a function of its potential production and price of rubber and found that supply elasticity with respect to price is low at 0.08 while the estimated elasticity of supply with respect to potential output is 2.08. To study the supply response of peach production in Tunisia, Laajimi et al. (2008) developed an econometric model in two stages. In the first stage area variation was explained through replanting and removal and in the second stage yield variation was analysed. They found very weak supply response to changes in expected prices with elasticity value of 0.13 indicating a high degree of inelasticity. 
Studies that analyse the supply response of perennial crops in Malaysia are relatively few. Talib (1988) examined the supply response of palm oil in Malaysia for the period 1961 to 1985 by estimating three area models. Own price and cross price elasticities with respect to rubber prices were estimated. While the study showed that palm oil area expansion was not significantly influenced by the price of rubber, the shortrun and long-run own price elasticities of palm oil was estimated to be 0.72 and 1.48 respectively. A relatively more recent study by Alias et al. (2001) examined the supply response of palm oil, rubber and cocoa for the period 1977-1997 using Engle-Granger single-equation cointegration approach (Engle and Granger, 1987). They modelled natural rubber production as a function of rubber pricing index, palm oil price index and government expenditure on agriculture and rural development and found the estimated elasticities to be $0.180,1.664$ and 1.751 respectively.

The present study is an attempt to examine the supply aspect of the market for rubber in Malaysia with the view to gaining better insight into farmer's responsiveness to changes in economic incentives. Accordingly, short-run and long-run supply elasticities of rubber will be estimated within a time series framework.

\section{Empirical Approach}

In modelling agricultural supply, it is customary to include both price and non-price factors in the supply response function. However, due to unavailability of data for several variables, the long-run equilibrium supply response of rubber in this study is the simple form:

$$
A P_{t}=\beta_{o}+\beta_{1} R P_{t}+\beta_{2} F P_{t}+\mu_{t}
$$

where, $A P$ is area planted, $R P$ is the relative price of natural rubber (that is, the ratio of rubber price to palm oil price) and $F P$ is the price of fertilizer, all variables are expressed in natural logarithm; and $\mu$ is a disturbance term. The nominal prices of rubber, palm oil and fertilizer are deflated by the Consumer Price Index (CPI) deflator $(2010=100)$. Area planted is taken to be the important decision variable in rubber supply as it measures intended supply and, unlike output, is more subject to the control of farmers.

A key assumption underlying classical regression is that the variables must be stationary. A stationary variable is one that is characterized by mean reversion in that it fluctuates around a constant long-run mean and has a time-invariant finite variance and a theoretical correlogram that diminishes as lag length increases. When variables are non-stationary, the use of standard statistical procedures, such as the Ordinary Least Squares (OLS), is ruled out since the variables change over time and are known to generate spurious regression results (Granger and Newbold, 1974). Consequently, conventional time series analyses require a priori investigation of the stochastic properties of the series through unit root and cointegration tests before any estimation is carried out.

First, a unit root test was applied to determine whether a variable is stationary or otherwise and also its order of integration. To transform variables to be stationary, the technique of differencing is commonly used and the number of times that a variable needs differencing to achieve stationarity is known as the order of integration of the variable. To this end, we employ the popular augmented Dickey-Fuller (ADF) and Phillips-Perron (PP) unit root tests in order to identify the order integration of each time series variable, both with or without deterministic trend (Dickey and Fuller, 1981; Said and Dickey, 1984). Determination of the order of integration of variables is crucial since standard cointegration tests require variables to be integrated of the same order. Secondly, we apply cointegration test to ascertain the presence of a long-run relationship between the variables of interest. Simply put, cointegration implies the long-run comovement of variables such that their linear combination is stationary even if individual time series are non-stationary. In this study, we apply the procedure proposed by Johansen (1988) and Johansen and Juselius (1990) which is based on the Vector Autoregressive (VAR) framework. The associated vector error correction model (VECM) of the VAR-based test can be represented as:

$\Delta Y_{t}=\alpha_{0}+\sum_{i=1}^{k} \alpha_{1} \Delta Y_{t-1}+\pi Y_{t-1}+\varepsilon_{t}$

where, $Y$ is a $n \times 1$ vector of $I(1)$ variables, $\Delta$ is the firstdifference operator such that $\Delta Y_{t}=Y_{t}-Y_{t-1}, k$ is the system lag order and $\varepsilon$ is the error term with zero mean, constant variance and zero covariance. Within the JohansenJuselius cointegrating framework, information about the number of independent cointegrating vector (denoted by $r$ ) is determined by the rank of $\pi$. Two sequential test procedures, namely, trace and maximum eigenvalue likelihood ratio test statistics are used to test for significant cointegrating vectors based on the Johansen (1988) multivariate procedure. Before implementing the JohansenJuselius test, the optimum lag length, i.e., one that renders the errors uncorrelated, is selected. In this study, we employ the Ljung-Box Q-statistic to test for autocorrelation of the error terms while the Schwarz Information Criterion (SIC) is used to determine the system lag order. On the basis of establishing $\mathrm{r}$ distinct cointegrating vectors, $\pi$ can be decomposed into two $n \times r$ coefficient matrices $\lambda$ and $\beta$. In other words, $\pi=\lambda \beta^{\prime}$ and thus:

$\Delta Y_{t}=\alpha_{0}+\sum_{i=1}^{k} \alpha_{1} \Delta Y_{t-1}+\lambda\left(\beta^{\prime} Y_{t-1}\right)+\varepsilon_{t}$ 
where, $\lambda$ measures the speed of adjustment, $\beta$ is a vector of long-run parameters and the term $\beta^{\prime} Y_{t-1}$ is the error correction term representing deviation from the long-run equilibrium. Accordingly, $\lambda$ is the coefficient of the error correction term and its magnitude measures the extent to which any deviation from the long-run equilibrium is corrected by adjustments in $Y$ (Hallam and Zanoli, 1993).

Based on establishing the presence of a cointegrating vector, the VECM model for rubber as given below is then estimated.

where all the variables have been defined above, $\Delta$ represents first difference operator, $\beta_{11}, \beta_{22}$ and $\beta_{33}$ are the short term coefficients, $\delta_{1}, \delta_{2}$ and $\delta_{3}$ are the long-run speed of adjustment coefficients and $\omega_{t}, v_{t}$ and $\phi_{t}$ are the stochastic error terms:

$$
\begin{aligned}
& \Delta A P_{t}=\beta_{10}+\sum_{i=1}^{n} \beta_{11 i} \Delta A P_{t-i}+\sum_{i=1}^{n} \beta_{12 i} \Delta R P_{t-i} \\
& +\sum_{i=1}^{n} \beta_{13 i} \Delta F P_{t-i}+\delta_{1}\left(A P-\theta_{1} R P-\theta_{2} F P\right)_{t-1}+\omega_{t} \\
& \Delta A P_{t}=\beta_{20}+\sum_{i=1}^{n} \beta_{21 i} \Delta A P_{t-i}+\sum_{i=1}^{n} \beta_{22 i} \Delta R P_{t-i} \\
& +\sum_{i=1}^{n} \beta_{23 i} \Delta F P_{t-i}+\delta_{2}\left(A P-\theta_{1} R P-\theta_{2} F P\right)_{t-1}+v_{t} \\
& \Delta A P_{t}=\beta_{30}+\sum_{i=1}^{n} \beta_{31 i} \Delta A P_{t-i}+\sum_{i=1}^{n} \beta_{32 i} \Delta R P_{t-i} \\
& +\sum_{i=1}^{n} \beta_{33 i} \Delta F P_{t-i}+\delta_{3}\left(A P-\theta_{1} R P-\theta_{2} F P\right)_{t-1}+\phi_{t}
\end{aligned}
$$

\section{Data and Empirical Analysis}

The data used in the analysis are annual time series from 1990 to 2014, a 25-year span capable of demonstrating the long-run relationship between the variables of interest. Data on rubber area planted and rubber price was obtained from the Malaysian Rubber Board natural rubber statistics while data on palm oil price are from the Malaysian Palm Oil Board. Data on the price of fertilizer and the CPI were obtained from Department of Agriculture and Department of Statistics, respectively.

As noted earlier, the determination of the time series properties of individual variables usually precedes VECM estimation. Therefore, we subject the series to ADF and PP unit root tests and the relevant test statistics are exhibited in Table 1. Both tests without deterministic trend reveal that all variables, with the exception of the area planted, are nonstationary or integrated of order 1 i.e., I(1). However, under a trended test, the rubber area planted is found to be stationary by the ADF test but non-stationary by the PP test. Choi and Chung (1995) maintain that when dealing with low-frequency data, as is the case in this study, the PP test tend to have more power than the ADF test. Consequently, in the analysis that follows, the study proposed treating the area planted variable as I(1) in levels.

The results of the cointegration test based on the Johansen-Juselius procedure are reported in Table 2. Based on SIC and the Ljung-Box Q-statistic, a lag length of 1 is chosen, which satisfactorily leaves the errors non-autocorrelated. As can be seen from the table, both the trace and maximum eigenvalue test statistics strongly provide evidence in support of a unique statistically significant cointegrating relationship among $A P_{t}, R P_{t}$ and $F P_{t}$. Thus, we can infer from this result that these variables are tied together in the long-run and their movements away from the long-run steady-state equilibrium path will be adjusted.

Hallam and Zanoli (1993) assert that where there exists only one co-integrating vector, it can be regarded as an estimate of the long-run co-integrating relationship between the relevant variables. Thus, this cointegrating vector was normalized with respect to area planted and interpreted as the long-run rubber acreage supply response function. Table 3 presents the long-run cointegrating vector as well as weak exogeneity tests, diagnostic tests, short-run estimates and tests of zero restrictions on the parameters of the error correction model.

The long-run coefficient signs and magnitudes are reasonable and consistent with a priori expectations. In particular, we find a positive and significant long-run association between $A P_{t}$ and $R P_{t}$ and a negative and significant long-run association between $A P_{t}$ and $F P_{t}$. Furthermore, the long-run elasticity of area planted with respect to both relative price $(0.77)$ and fertilizer price (0.28 ) are inelastic implying that in the long-run Malaysian rubber farmers can make only small adjustments to area planted in response to changes in these prices. Our estimated long-run price elasticity of 0.77 differs from the 0.18 reported by Alias et al. (2001). However, it should be noted that while this study employs the ratio of rubber to palm oil price (relative price), Alias et al. (2001) emphasized the prices of rubber and palm oil individually.

The weak exogeneity test is useful in revealing the variables that carry the burden of adjustments toward the long-run equilibrium path (Ibrahim and Law, 2014; Johansen, 1992). The results indicate that while the null of weak exogeneity for $A P_{t}$ and $F P_{t}$ are rejected (thus area planted and fertilizer price are not weakly exogenous), that of $R P_{t}$ is strongly rejected (The interest of this study is on acreage response and thus the shortrun estimates in the fertilizer equation are suppressed to optimize space. However, these estimates are available upon request). We therefore surmise that the relative price is weakly exogenous and is unresponsive to changes in area planted and fertilizer price. Thus, the relative price can be interpreted as the forcing variable that induces adjustments in acreage and fertilizer price to reinstate the long-run equilibrium. 
Table 1. ADF and PP unit root test

\begin{tabular}{|c|c|c|c|c|}
\hline \multirow[b]{2}{*}{ Level variable } & \multicolumn{2}{|c|}{ Augmented Dickey Fuller (ADF) } & \multicolumn{2}{|l|}{ Phillips-Perron (PP) } \\
\hline & Constant without trend & Constant with trend & Constant without trend & Constant with trend \\
\hline$\overline{\mathrm{AP}}$ & $-0.775(0)$ & $-3.849 * *(3)$ & $-0.773[1]$ & $-2.502[0]$ \\
\hline $\mathrm{RP}$ & $-2.103(0)$ & $-3.017(1)$ & $-2.185[2]$ & $-2.559[2]$ \\
\hline FP & $0.587(0)$ & $-1.847(0)$ & $1.153[13]$ & $-1.650[9]$ \\
\hline \multicolumn{5}{|l|}{ First difference } \\
\hline AP & $-4.675 * * *(0)$ & $-4.600 * * *(0)$ & $-4.675 * * *[1]$ & $-4.595 * * *[2]$ \\
\hline RP & $-4.367 * * *(1)$ & $-4.199 * *(1)$ & $-4.052 * * *[8]$ & $-3.828 * *[8]$ \\
\hline FP & $-4.650 * * *(0)$ & $-5.167 * * *(1)$ & $-4.653 * * *[7]$ & $-9.351 * * *[22]$ \\
\hline
\end{tabular}

Note: $* * *$ and $* *$ denotes significant at 1 and 5\% significance level, respectively. The figure in parenthesis (...) represents optimum lag length selected based on Schwarz Info Criterion. The figure in bracket [...] represents the Bandwidth used in the PP test selected based on Newey-West Bandwidth criterion using Bartlett kernel.

Table 2. Johansen-juselius multivariate cointegration tests

\begin{tabular}{|c|c|c|c|c|}
\hline \multirow[b]{2}{*}{ Null hypothesis } & \multirow[b]{2}{*}{$\begin{array}{l}\text { Trace } \\
\text { Statistic }\end{array}$} & \multirow[b]{2}{*}{$\begin{array}{l}\text { Max-Eigen- } \\
\text { Statistic }\end{array}$} & \multicolumn{2}{|c|}{ Critical values (5\%) } \\
\hline & & & Trace & Max-Eigen \\
\hline $\mathrm{r}=0$ & $33.610^{* *}$ & $23.420 * *$ & 29.680 & 20.970 \\
\hline$r \leq 1$ & 10.190 & 8.248 & 15.410 & 14.070 \\
\hline$r \leq 2$ & 1.942 & 1.942 & 3.760 & 3.760 \\
\hline
\end{tabular}

Note:** denotes significant at 5\% significance levels. The 5\% critical values are from Osterwald-Lenum (1992). The VAR lag length selected for the test is 1 , which we find adequate to make the error term serially uncorrelated.

Table 3. Long-run and short-run estimates based on VECM

Long Run Estimates (normalized on $A P_{t}$ )

Constant

13.950

$R P_{t}$

$F P_{t}$

Weak exogeneity tests (LR statistic)

$A P_{t}$

$R P_{t}$

$F P_{t}$

Short-run estimates

$\triangle A p_{t-1}$

$\Delta R P_{t}$

$\Delta F P_{t-1}$

$E C T_{t-1}$

Diagnostic tests

$\mathrm{R}^{2}$

BG-LM (2)

JB

ARCH (2)

ARCH (4)

Wald test of zero restrictions

Chi-square $\left(x^{2}\right)$

$0.774(3.514)$

$-0.278(-2.225)$

$7.921[0.005]$

$2.638[0.104]$

$5.604[0.018]$

$0.258 *(2.026)$

$0.044 *(1.870)$

$-0.197 * * *(-6.366)$

$-0.056^{* *}(-2.800)$

0.612

$0.591[0.744]$

$0.965[0.617]$

$0.931[0.628]$

0.940 [0.919]

$45.688[0.000]$

Note: ***,** and * denote significant at 1,5 and $10 \%$ levels, respectively. Figures in parenthesis (...) are t-statistics while figures in brackets $[\ldots]$ are p-values.

The estimated coefficient of the one-lagged error correction term $\left(E C T_{t-1}\right)$ which captures acreage adjustment towards the long-run equilibrium is statistically significant and carries the expected (negative) sign, further providing evidence in support of the existence of an equilibrium relationship between acreage, relative and fertilizer prices. The coefficient of 0.056 suggests that only about $5.6 \%$ of the deviation of rubber acreage from the long-run equilibrium level is corrected per year. Thus, any short-run deviation will take approximately 17.8 years to adjust to long-run equilibrium, a rather slow adjustment. The short-run elasticities represented by the coefficients of the difference terms with respect to the relative price and fertilizer price are consistent with theoretical expectations in terms of both signs and magnitudes; the short-run elasticities of acreage is 0.04 for relative prices and -0.20 for fertilizer prices.

In terms of model adequacy, the diagnostic tests show that the equation statistically performs quite sufficient in explaining rubber supply response. In particular, the null hypothesis of no autocorrelation in the residuals is not rejected by the Breusch-Godfrey LM (BG-LM) test for autocorrelation. The hypothesis of normality in the residuals could not be rejected by the Jarque-Berra (JB) statistic, indicating that the residuals are normally distributed. In addition, tests for ARCH residuals suggest that the assumption of homoskedasticity is not violated.

As noted by Hendry et al. (1984) and Hallam and Zanoli (1993), the more restrictive Nerlovian partial adjustment model and the VECM are both encapsulated inside a general autoregressive distributed lag model. In order to discriminate between these specifications, an imposition of zero restrictions on the parameters of the difference terms in the error correction model was assumed. The results of the Wald test gives a $x^{2}$ of 45.68 , which strongly rejects the additional restrictions imposed by the partial adjustment model. Thus, the VECM is superior to the partial adjustment model in 
appropriately describing the data. This conclusion is consistent with the findings of Abdulai and Rieder (1995) in the case of cocoa supply response in Ghana and Soontaranurak and Dawson (2015) in case of rubber acreage response in Thailand.

\section{Conclusion}

The supply responsiveness of agricultural commodities to economic incentives has received the attention of policy-makers in recent years due to its role in determining the efficacy of government intervention in the agricultural sector. This paper contributes to this line of interest by assessing the long-run relationships between Malaysian rubber acreage, relative price of rubber and fertilizer price. The empirical analysis relies on time series techniques and is organized within the VECM framework to obtain short-run and long-run rubber acreage elasticities.

We establish the presence of a unique long-run equilibrium relationship between planned supply proxied by the planted acreage and its determinants namely, relative price and fertilizer price and that the relative price of rubber is unresponsive to changes in acreage and fertilizer price. Further, the estimated short- and long-run elasticities of acreage with respect to relative price are respectively 0.04 and 0.77 , indicating that although Malaysian rubber farmers respond rationally to price incentives, rubber supply is inelastic both in the shortand long-run. In terms of input price, the short- and longrun elasticities of acreage with respect to fertilizer price are -0.20 and -0.28 respectively. The coefficient of the error correction term is -0.056 and statistically significant, suggesting a rather slow speed of adjustment and hence an extended phase of disequilibrium in the markets before long-run equilibrium is achieved.

Furthermore, an increase in the income of farmers, occasioned by appropriate output and input prices, is crucially important in dealing with agrarian distress and improving the competitiveness of farms. As their income increase, farmers are able to put into effect new technological innovation and modern scientific measures, for example, by purchasing yield-improving inputs such as equipment, seeds, pesticides and chemical fertilizers capable of increasing productivity which, in turn, has been recognized as the main driver of income increases in agriculture. In addition, higher income broadens the resources available to farmers making it possible to expand production and for crop diversification to occur. What is more, rural exodus, which is exacerbated by factors such as the attraction of higher urban wages, is reversed by better farm incomes which make farming become a more sustainably attractive profession for youths and motivates young people. Thus, higher farmer's income increases the competitiveness of farms, avoiding in many cases rural exodus phenomenon.
Overall, our econometric estimates of the rubber supply response function for Malaysia provide strong evidence in support of the efficacy of pricing policy in influencing planned supply. Thus, in order to significantly increase farm output and hence the income of farmers, developing an appropriate incentive structure should be the objective of Malaysian agricultural pricing policy.

\section{Acknowledgement}

The authors are very thankful and acknowledge to Universiti Putra Malaysia for facilitations of research.

\section{Funding Information}

The authors are very grateful to Universit Putra Malaysia for providing funds and facilities to create new knowledge and publication opportunities for its researchers.

\section{Author's Contributions}

Ghulam Mustafa: As a project leader and leading author he contributed in the paper by designing, conception of the manuscript. He executed and participated in all activities such as drafting, analysis interpretations of results.

Ismail Abd Latif: As a corresponding author he contributed in the paper by designing it. He helped in reviewing, analysis and interpretations of results and paraphrasing with addition to all corrections suggested by reviewers.

Henry Egwuma: He provided all the technical helps such as software application for current analysis, how to do analysis and run programs for current analysis. He also helped in paraphrasing of the manuscript.

\section{Ethics}

This paper was an individual class assignment of advance econometric class that has not been published or presented before in any journal and/or conferences.

\section{References}

Abdulai, A. and P. Rieder, 1995. The impacts of agricultural price policy on cocoa supply in Ghana: An error correction estimation. J. Afr. Econom., 4: 315-335.

Akiyama, T. and P.K. Trivedi, 1987. Vintage production approach to perennial crop supply: An application to tea in major producing countries. J. Econometr., 36: 133-161. DOI: 10.1016/0304-4076(87)90047-9

Alias, M.H., A.M. Ali and M.A. Rahman, 2001. The impact of government policy on the supply response of Malaysian palm oil, rubber and cocoa producers. Utara Manage. Rev., 2: 41-64. 
Alston, J.M., J.W. Freebairn and J.J. Quilkey, 1980. A model of supply response in the Australian orange growing industry. Aus. J. Agric. Econom., 24: 248-267.

DOI: $10.1111 / \mathrm{j} .1467-8489.1980 . t b 00581 . \mathrm{x}$

Arifin, B., 2005. Supply-chain of Natural Rubber in Indonesia. J. Manajemen Agribisnis, 2: 1-16.

Bateman, M.J., 1965. Aggregate and regional supply functions for Ghanaian cocoa, 1946-1962. J. Farm Econom., 47: 384-401. DOI: 10.2307/1236584

Behrman, J.R., 1968. Supply response in underdeveloped agriculture: A case study of four major annual crops in Thailand, 1937-1963. NorthHolland Publishing Co., Amsterdam.

Choi, I. and B.S. Chung, 1995. Sampling frequency and the power of tests for a unit root: A simulation study. Econom. Lett., 49: 131-136.

DOI: 10.1016/0165-1765(95)00656-Z

Devadoss, S. and J. Luckstead, 2010. An analysis of apple supply response. Int. J. Produc. Econom., 124: 265-271. DOI: 10.1016/j.ijpe.2009.11.024

Dickey, D.A. and W.A. Fuller, 1981. Likelihood ratio statistics for autoregressive time series with a unit root. Econometrica: J. Econometric Society, 49: 1057-1072. DOI: DOI: 10.2307/1912517

Elias, A. and A. Okorie, 2014. Effect of price changes on the supply response of rubber in Nigeria. J. Agric. Vet. Sci., 7: 39-42.

Engle, R.F. and C.W.J. Granger, 1987. Co-integration and error correction: Representation, estimation and testing. Econometrica: J. Econometric Society, 55: 251-276. DOI: $10.2307 / 1913236$

French, B.C. and J.L. Matthews, 1971. A supply response model for perennial crops. Am. J. Agric. Econom., 53: 478-490. DOI: 10.2307/1238225

Granger, C.W. and P. Newbold, 1974. Spurious regressions in econometrics. J. Econometr., 2: 111-120. DOI: 10.1016/0304-4076(74)90034-7

Gunawardana, P.J., H. Kidane and N. Kulendran, 1995. Export supply response of the Australian citrus industry. Aus. J. Agric. Econom., 39: 247-261. DOI: $10.1111 /$ j.1467-8489.1995.tb00553.x

Hallam, D. and R. Zanoli, 1993. Error correction models and agricultural supply response. Eur. Rev. Agric. Econom., 20: 151-166. DOI: 10.1093/erae/20.2.151

Hendry, D.F., A.R. Pagan and J.D. Sargan, 1984. Dynamic Specification. In: Handbook of Econometrics, Griliches, Z. and M.D. Intriligator (Eds.), pp: 1023-1100.

Huq, A.S.M.A. and F.M. Arshad, 2010. Supply response of potato in Bangladesh: A vector error correction approach. J. Applied Sci., 10: 895-902. DOI: $10.3923 /$ jas.2010.895.902

Huq, A.S.M.A., F.M. Arshad and G.N. Islam, 2013. Supply response of wheat in Bangladesh: Cointegration and vector error correction analysis. Afr. J. Agric. Res., 8: 5440-5446.
Ibrahim, M.H. and S.H. Law, 2014. House prices and bank credits in Malaysia: An aggregate and disaggregate analysis. Habitat Int., 42: 111-120. DOI: $10.1016 /$ j.habitatint.2013.11.006

Johansen, S., 1988. Statistical analysis of cointegration vectors. J. Economic Dynam. Control, 12: 231-254. DOI: $10.1016 / 0165-1889(88) 90041-3$

Johansen, S., 1992. Cointegration in partial systems and the efficiency of single-equation analysis. J. Econometr., 52: 389-402. DOI: 10.1016/0304-4076(92)90019-N

Johansen, S. and K. Juselius, 1990. Maximum likelihood estimation and inference on cointegration with applications to the demand for money. Oxford Bull. Econom. Stat., 52: 169-210. DOI: $10.1111 /$ j.1468-0084.1990.mp52002003.x

Kumar, P. and A. Sharma, 2006. Perennial crop supply response functions: The case of indian rubber, tea and coffee. Ind. J. Agric. Econom., 61: 630-646.

Laajimi, A., A. Guesmi, A. Mahfoudhi and B. Dhehibi, 2008. Analyzing supply response of fruit tree products in Tunisia: The case of peaches. Agric. Econom. Rev., 9: 24-34.

MRB, 2015. Research and innovation department. Malaysian Rubber Board.

Mesike, C.S., R.N. Okoh and O.E. Inoni, 2010. Supply response of rubber farmers in Nigeria: An application of vector error correction model. Agric. J., 5: 146-150. DOI: 10.3923/aj.2010.146.150

Mohammad, S., M.S. Javed, B. Ahmad and K. Mushtaq, 2007. Price and non-price factors affecting acreage response of wheat in different agro-ecological zones in Punjab: A co-integration analysis. Pak. J. Agric. Sci., 44: 370-377.

Mushtaq, K. and P.J. Dawson, 2002. Acreage response in Pakistan: A co-integration approach. Agric. Econom., 27: 111-121. DOI: $10.1111 / \mathrm{j} .1574-0862.2002 . t b 00110 . \mathrm{x}$

Mustafa, G., I.A. Latif, S.Z. Shah and M.K. Bashir, 2016. Nexus between $\mathrm{CO} 2$ emission, energy consumption and economic growth in ASEAN countries plus China. Am. J. Environ. Sci., 12: 299-307. DOI: 10.3844/ajessp.2016.299.307

NKEA, 2011. Retrieved on February 4, 2015. National Key Economic Areas.

Nerlove, M. and K.L. Bachman, 1960. The analysis of changes in agricultural supply: Problems and approaches. J. Farm Econom., 42: 531-554. DOI: $10.2307 / 1235403$

Osterwald-Lenum, M., 1992. A note with quantiles of the asymptotic distribution of the maximum likelihood cointegration rank test statistics. Oxford Bull. Econom. Stat., 54: 461-472. DOI: $10.1111 /$ j.1468-0084.1992.tb00013.x

Ozkan, B., R.F. Ceylan and H. Kizilay, 2011. Supply response for wheat in Turkey: A vector error correction approach. New Medit., 3: 34-38. 
Pipitkul, P., 2004. Demand and supply of natural rubber of Thailand. J. Agric. Econom. Agric. Econom. Society Thailand Under Royal Patronage, 23: 65-97.

Rahji, M.A.Y., O.O. Ilemobayo and S.B. Fakayode, 2008. Rice supply response in Nigeria: An application of the nerlovian adjustment model. Agric. J., 3: 229-234.

Said, S.E. and D.A. Dickey, 1984. Testing for unit roots in autoregressive-moving average models of unknown order. Biometrika, 71: 599-607. DOI: $10.1093 /$ biomet/71.3.599

Shahbaz, M., M. Shahbaz Shabbir and M. Sabihuddin Butt, 2013. Effect of financial development on agricultural growth in Pakistan: New extensions from bounds test to level relationships and granger causality tests. Int. J. Social Econom., 40: 707-728. DOI: 10.1108/IJSE-01-2012-0002
Soontaranurak, K. and P. Dawson, 2015. Rubber acreage supply response in Thailand: A cointegration approach. J. Develop. Areas, 49: 23-38.

DOI: $10.1353 /$ jda.2015.0009

Talib, B.A., 1988. Supply response analysis of palm oil in Malaysia 1961-1985. J. Ekonomi. Malaysia, 18: 3-25.

Tekasakul, P. and S. Tekasakul, 2006. Environmental problems related to natural rubber production in Thailand. J. Aerosol Res., 21: 122-129. DOI: $10.11203 /$ jar.21.122

Tripathi, A. and A.R. Prasad, 2009. Estimation of agricultural supply response by cointegration approach. Ind. Econom. J., 57: 106-131. 